\title{
The right to infrastructure: a prototype for open source urbanism
}

\begin{abstract}
This article develops an analytical framework to place the rise of open source urbanism in context, and develops the concept of the 'right to infrastructure' as expressive of new ecologies of urban relations that are heretofore coming into being. It describes, first, a genealogy for open source technology, focusing in particular on how open source urban hardware projects may challenge urban theory. It moves then to describe in detail various dimensions and implications of an open source infrastructural project in Madrid. In all, the article analyses three challenges that the development of open source urban infrastructures are posing to the institutions of urban governance and property: regarding the evolving shape and composition of urban ecologies; the technical and design challenges brought about by open source urban projects, and; the social organisation of the 'right to infrastructure' as a political active voice in urban governance. In the last instance, the right to infrastructure, I shall argue, signals the rise of the 'prototype' as an emerging figure for contemporary socio-technical designs in and for social theory.
\end{abstract}

Keywords: open source urbanism; infrastructures; urban ecologies; urban commons; right to the city; prototypes

What would a city look like if its infrastructures were designed, built, certified and managed by its residents? Cities worldwide are witnessing today a transformation 
of their material and infrastructural landscapes. In the name of 'open technology', 'open hardware' or, more amply, 'open source urbanism', citizens are wiring the landscape of their communities with the devices, networks or architectures that they deem worthy of local attention or concern. From community urban gardens to alternative energy microstations or Wi-Fi networks, open source hardware projects wireframe the city with new socio-technical relations. Such interventions in the urban fabric are transforming, if not directly challenging the public qualities of urban space. Public spaces become technomaterial artefacts that citizens take upon themselves to service and maintain.

This article develops an analytical stance to place the rise of open-source urbanism in context. It does so by surveying, first, the genealogical and conceptual purchase of the open source movement. Next, it moves to explore the concomitances of an open source urban hardware project in the city of Madrid, developing in the process a theoretical space for the novel epistemic work that such 'prototypes' (as I shall henceforth refer to them) are seen to be doing. In brief, the argument focuses on three challenges that the development of open source urban infrastructures is posing to the institutions of urban governance and property:

1. Conceptually, projects in open source urbanism are populating urban ecologies with novel entities and interfaces - digital and material - whose emergence destabilizes classical regulatory distinctions on what were hitherto deemed public, private or commercial property-forms, technologies and spaces. Who and what is urban space made-up of when its equipment and infrastructures are open source?

2. Technically, open source urban projects are built on networks of expertise and skills that traverse localized boundaries. Decentralized communities working in open source projects have to reach prior consensus over the methods, protocols and standards 
to be applied. These decisions often become inventive themselves of new designs, techniques and rules for certification.

3. Politically, open source projects are transforming the stakes over and models of urban governance. In an open source project a community assumes political and expert management over its infrastructures. Such assumption by local communities of the governance of infrastructures is straining the social contract that state administrations have traditionally subscribed as overseers of urban equipment.

Building on recent developments in social anthropology, social studies of science and technology, and urban studies, here I aim to offer an original analytical framework for the study of open source urbanism as a novel expression and assemblage of public and collective action, one which I tentatively name a 'right to infrastructure'.

I have coined the term 'right to infrastructure' to echo deliberately Henri Lefebvre's famous notion of the 'right to the city' (Lefebvre, 1996), which has become more recently an emblem of urban social movements worldwide (Mitchell, 2003; Purcell, 2013). However, as I develop it here, the right to infrastructure is neither a human-centred 'entitlement', part of what may be thought as human-rights approaches to urban social justice; nor is it either an object or device whose novel (say, sensor or network) capabilities 'claim' recognition in an urban ecology. It is neither a right to infrastructure nor an infrastructure made right. Rather, the right to infrastructure allows us to escape the human-nonhuman / epistemology-ontology dichotomy altogether by opening-up the agential work of infrastructures as a source (an open source) of possibilities in their own right.

Central to this idea of open source urban hardware projects as expressive of a right to infrastructure is their status as 'prototypes'. The prototype, as I shall refer to it here, is an emerging socio-material design for our contemporary whose main quality is 
its permanent 'beta' condition; that is, whose social and material components retrofit each other as being in mutual suspension (XXX, In print). The example par excellence of a socio-technical prototype is free software, where the infrastructure (code) is selfgrounded by the very collaborative effort that sets it in motion (Kelty 2008). I shall return to the notion of the prototype later again in the argument. For the time being, let me note that this peculiar 'prototyping' status of open source hardware projects offers also a provocative port-of-call for documenting the emergence of novel ecological assemblages in urban contexts, in particular the work of 'expressive infrastructures' mediating digital, material and social relations (Thrift, 2012). The analysis of open source infrastructures allows thus for an original approach to the study of the technical and social assemblages that have come to be known as 'sentient' or 'cyborg' cities (Shepard, 2011a; Gandy, 2005). Furthermore, open source urban hardware projects offers also a novel point of entry into on-going debates about the status of intellectual property and patent forms under rapidly shifting regimes of informational capitalism (Biagioli et al., 2011), in particular as they affect claims over emerging 'urban commons' (Harvey, 2012).

The rest of the article is in three parts. In the first part I briefly situate the ascent of open source hardware within the larger genealogy of the free and open source (F/OS) movement, in particular the rise of F/OS software. Here I do not aim so much to produce a deep historical or comparative survey of developments to date, as to point to some of the key debates surrounding the political and technical implications of open source projects, for some of these questions affect profoundly how urban ecologies are modulated by certain infrastructural developments.

In the second part of the essay I describe different dimensions of an open source urban project in Madrid. This is based on over two years of ethnographic fieldwork with 
a variety of self-described open source architectural collectives in the city. The description includes a recent turn of events where I have myself participated in a reinscription of certain open source infrastructural projects as pedagogical and educational initiatives in the city. Overall, I place the project within a recent current in urban studies that pays attention to the wiring of novel sensor- and network capabilities into emerging ambient and sentient ecologies, and inquire into how these ecologies may be modulated when the processes through which they are inscribed and wired remain open-ended.

I bring the argument to a close in the last section by outlining some of the challenges and disruptions that thinking with and through open source infrastructures is likely to pose to urban and social theory at large.

\section{Open source infrastructures}

The open source movement has drawn considerable attention of late. 'Openness' has become a favoured slogan for describing the epistemic pressures and transformations undergone by the political economy of knowledge and techno-science in the age of informational capitalism. Thus, whilst some authors have argued that the structure of digital information - in particular the negligible costs of reproduction - instantiates a de facto regime of superabundant or 'open knowledge' (Foray, 2006, pages 172-179), others have alerted towards the enclosure of such informational commons by existing proprietary regimes (Boyle, 2008). However, as Charlotte Hess and Elinor Ostrom have pointed out, it is worth remembering that access to information depends to this day on the maintenance and management of complex infrastructural facilities. Their suggestion is to think of information not as a superabundant commons but as a common-pool resource (Hess and Ostrom, 2003): a resource that requires storage and preservation, 
and over which one must define rights and rules of access, extraction, exclusion and alienation (Hess and Ostrom, 2006, page 7).

Whilst the economic and political underpinnings of open knowledge are on the whole well understood, there are fewer studies of the cultural practices and social organisation characteristic of such initiatives. In this regard, one of the aspects of the new economy of open knowledge that has received most commentary to-date is its grounding in novel organisational forms, in particular so-called peer-to-peer networks of collaboration (Benkler, 2006). The common view here is that peer-to-peer decentralized networks are blurring traditional distinctions between production, distribution and consumption of informational-forms. In this economy, users become themselves producers of content (so-called 'prosumers'), and cooperation becomes the economy's main, if not only dynamo (Benkler, 2011).

Although the organisational qualities of $\mathrm{F} / \mathrm{OS}$ software projects have been much commented on (Ghosh, 2005), in-depth or ethnographic studies of F/OS cultures are much harder to come by. Chris Kelty's historical and ethnographic account of the development of free software has already become a classic in the field (Kelty, 2008). Kelty has suggested that communities of free software developers may be conceptualized as 'recursive publics': a form of public sphere where the architectural framework for debate and exchange is self-grounded through the very activity of writing, editing, patching or recompiling the infrastructure (code) upon which programmers work. In a recursive public, technology is deployed 'as a kind of argument, for a specific kind of order: [free software developers] argue about technology, but they also argue through it. They express ideas, but they also express infrastructures through which ideas can be expressed (and circulated) in new ways.' (Kelty, 2008, page 29, emphases in the original) The notion of a 'recursive public' 
offers, then, a very useful analytical framework with which to rethink the nature of politics when the infrastructures of participation are themselves open to (self-) modulation.

Gabriella Coleman's recently published ethnography of the ethics and aesthetics of hacking similarly draws on long-term anthropological engagement with free software programmers (Coleman, 2012). Whilst Kelty draws attention to the structural innovation that 'recursivity' poses to public sphere theories, Coleman focuses instead on the cultures of liberalism that hacking enacts. According to Coleman, the toils and pleasures of hacking reveal a contradictory and tense relationship with (American) traditions of political liberalism. Hacker attitudes and work routines simultaneously challenge and take residence within liberal conceptions of freedom, labour and intellectual property. Thus, whilst some hackers work towards protecting individual autonomy from intrusive corporate behaviour, others promote an experience of autonomy and freedom that rejoices on the virtues of sharing and pedagogy. And yet other programmers take pleasure in the culture of transgression that characterises certain underground hacker practices (see also Coleman and Golub, 2008).

These innovative ethnographies of F/OS projects have shown how interventions in the domains of technology and property may also be conceptualized as interventions in the domains of collaboration and social and political invention; indeed, how these in fact subtend all politics as infrastructural politics. There is a historical lesson worth briefly rehearsing here, about the proprietorial and sociological frameworks and traditions that such infrastructural politics has contributed to exposing. According to Fred Turner (2006), digital utopianism, the hacker ethics and the political economy of peer-to-peer collaboration are long-term developments from Norbert Wiener's interdisciplinary post-war experiments in cybernetic philosophy (Wiener, 1989), and in 
particular from the do-it-yourself, environmental and 'homebrew' computing countercultural movements that cybernetics inspired. In this reading, the philosophy of cybernetics is deemed responsible for laying the conceptual ground for talking of 'informational exchanges', virtual communities or digital economies of cooperation more amply. It contributed towards the understanding of open sourced information as a political technology.

It is hardly coincidental, therefore, that the original impetus and advocacy for free software as a non-proprietary technology took root in the context of such countercultural movements. For indeed what first sparked the creation of free software licenses - and has remained the most important cultural and political innovation in free and open source $(\mathrm{F} / \mathrm{OS})$ projects over the past thirty years - has been the status of 'openness' as a proprietary object. The creation of the GNU General Public Licence (GPL) by Richard Stallman in the 1980s, which is the original and archetypical license on which F/OS software programmes run, is famous for first hacking copyright law by inventing a 'copyleft' license (Kelty, 2011). But the controversy surrounding its original development is echoed today in almost all debates concerning the legal status of digital objects (Gillespie, 2007). These include discussions about the intangibility, materiality and legal agency of software and digital objects; the distinction and/or breakdown of the idea/expression dichotomy; and the ensuing problem of adjudicating between creativity, collaboration or shared practice in software development. What is a copyrightable object (code, firmware, binaries); who are the (collective, individual, relational) subjects of rights; or how do these various distinctions map onto political, social and ethical categories (the public domain, freedom, the commons) - these are all controversial debates that have been spurned anew by the digital revolution (Biagioli et al., 2011). 
The study of open source urban hardware projects participates of these debates. But it does so with a peculiarity that poses in turn a formidable challenge to - and is spurning considerable innovations in - property forms and law. For the licensing of designs in open hardware projects falls in most countries under the jurisdiction of patent law, not copyright law.

Unlike F/OS programmes, open source hardware projects produce tangible outputs - artefacts, devices, machines. According to the Open Source Hardware Definition and Statement of Principles what makes a piece of hardware 'open' is its design process (OSWH Draft, Definition of Free Cultural Works). It is the design, not the object qua object that remains open. This makes open source hardware fundamentally different from F/OS software, in that design and output do not coincide in the same object. In software the code is the design and the infrastructure; in hardware, the tangible output is assembled from the design. In other words, the source of openness in open source hardware is the design.

The design of an open source hardware project encompasses therefore both the design of its hardware and software and the documentary record of its design process. That is, one needs to make explicit how (in what formats, files, stages, languages) is the process of design described, documented and published. Step by step such documentary registry spells a methodology of design. Hardware design documentation includes for example mechanical drawings, circuit-board layouts, photographs or descriptive texts. There are many layers to a design and open source hardware projects require that every native component of a design be rendered 'open', or that if a portion of the design is not released under a F/OS license it be dutifully noted.

An important consequence of the role played by the methodology of design in the standardisation of an open hardware project is its legal affordances. Open source 
hardware licenses are generally limited to controlling the circulation of design documents and have no purchase over manufactured objects. In open source hardware, then, the method of design is turned into a social form with proprietary effects: that is, the organisation of the network of collaborators, the material qualities of components, formats and layers (photographs, sketches, code), and the methods of description and documentation are all entangled in the social process of making/hacking property. Property is not the outcome/output of a design process, but the very design process itself. The question of what is open - and how the process of opening-it up is carried out - when the underlying object is hardware rather than software, remains, therefore, a hotly contested issue, and one about which little is known to-date.

\section{Urban intelligences 'in beta'}

Although there have been some recent reports of the application of open source hardware technologies to urban contexts, most of these remain experimental and descriptive. Using the open source microcircuit board Arduino, for example, experimental and environmental artists David Benjamin and Soo-in Yang (The Living) and Natalie Jeremijenko (xdesign Environmental Health Clinic at Columbia University) have reported on the design and development of a set of sensors aimed at measuring water quality and aquatic life in the East River and Bronx River in New York. Known as Amphibious Architecture, the aquatic sensor-interface aims to employ the technological affordances of ubiquitous computing to expand the ontological register of ‘interaction partners for environmental governance' (Benjamin et al., 2011). The Spanish architect Nerea Calvillo similarly resorted to the Arduino platform for developing a 'mechanical prototype' of Madrid's atmospheric conditions (Arbona, 2010). The prototype emits aerosol clouds that change colour as they interact with the 
city's air. The vapours and fogs and 'invisible landscapes' of the city, as Calvillo calls them, are thus rendered colourfully visible. In the Air, as the project is known, envisions a future where people can install or carry their own prototypes around, illuminating the chromatic densities of the atmospheres they inhabit or walk about. A time, then, when air ceases to be something that envelops and surrounds us, but something, rather, that we can infrastructure - envelop and surround - into a colourful cloud to be pointed at, maybe even shifted and moved around (Arbona, 2010, pages 93-94).

How to think of these open source architectural and infrastructural interventions in an urban ecology? There is of course a distinguished tradition in critical urban geography that has long studied the role of technology in the configuration of urban ecologies. Thus, a well-known line of inquiry has looked into the socio-technical constitution of urban spaces as ecosystems of 'metabolic' exchanges between 'natural, real, fictional, mechanical and organic' processes (Swyngedouw, 1996, page 66). Although much of this literature is articulated as an explicitly Marxian critique of the political economy of metropolitan environments (Swyngedouw and Heynen, 2003), there has also been an interest in the internal development of infrastructure as placeholder of public and collective agencies: that is, where devices and technologies are not just conduits for the transference and circulation of capital as the ultimate enveloper of the urban eco-sphere, but where these are seen as themselves enabling of novel social and political forms of association. These complex entanglements of social, material and machinic capacities have led some authors to speak of 'cyborg urbanization' (Gandy, 2005). The cyborg concept is enlisted here to critically examine how social bodies, machines and spaces enhance or distort received assumptions as to what may count as, or where to look for, an urban public sphere. A cyborgian public realm does not simply respond, as Matthew Gandy has observed, to the 
communicational, neo-organicist or metabolic enhancements afforded by machine- and networked exchange circuits, but 're-materializes' (Gandy, 2005, page 40) the very terms through which these processes transform the relations between the body, the human subject and urban- and/as life-support systems.

More recently, the supplemental or prosthetic capabilities of urban cyborg organisms have been revisited following the sensorial enhancements afforded by new digital technologies and sensors. Cities are getting 'smarter', we are told, as information processing technologies and ubiquitous computing systems get embedded in our urban landscapes. We live in a world of sensorial and value richness, an environs supercharged by the digital augmentations afforded by network connectivity. These are 'sentient cities' (Shepard, 2011b) whose architectures foil our environs with 'ambient intelligences' (Crang and Graham, 2007). According to Nigel Thrift, this process takes place through the deployment of novel 'expressive infrastructures' (tiny microprocessors and wireless sensor networks) that 'thicken space' and cloak our surroundings with the atmospheric pressures and intensities of 'some of the characteristics of weather.' (Thrift, 2012, pages 4, 17, 15) Mark Shepard likewise speaks of 'informatic weather systems' (Shepard, 2011b, page 18) whose invisible (digital) winds and currents are steeping our surroundings with the powers of anticipation and memory, turning citizens into statistically predictable data-subjects, conducing towards a politics of inter- and intra-visibility that is in effect construing a militarisation of intimacy (Graham, 2010). The infrastructures of cities are thus contoured as 'transductive' landscapes of social relations and code (MacKenzie, 2006) that can now sound and monitor our locations, movements, even normalize the interiority of behaviour, both for commercial, regulatory or military purposes. Thus, capabilities, skills and forms of sentience once ascribed to human actors are today being 
re-inscribed into sensor-landscapes and networks. They are also being placed and distributed along topographies that escape expert governance (Sassen, 2011). F/OS WiFi networks, for instance, lay out geographies of political communication that circumvent public and private telecommunication systems. The political ecology of urban infrastructures is thus redrawn and repopulated with novel artefacts, actors and socio-technical relations.

Whilst the increasing use of pervasive computing in urban design is well documented, much of this literature remains concerned with transformations in the technical capacities and equipment of architecture and the built environment (Burke and Tierney, 2007; McCullough, 2005). Critical and empirical scholarship on the social uses and development of these technologies is harder to come by, although there is of course a long and well-established record of studies in cultural theory and architectural history on the role of artistic vanguards in calling out and provoking novel reconceptualisations of the political ecology of cities (Sadler, 2005, 1999; Wark, 2008).

In light of the above, open source urbanism may be thought-of as a manifestation of this expanded cyborg or transductive urbanization. Yet the role of infrastructure and hardware as 'recursions' (in Chris Kelty's sense) of a community's social and political presence opens novel theoretical and empirical avenues for thought, for the transductive dimensions (the sensors, the code) need no longer be thought as extending or supplementing social capacities but as a form of sociality 'in beta' (XXX, In print). Relations 'in beta' have a depth to them that we might call infrastructural, in that they hold the social and material in mutual suspension. The infrastructure is not something that gets 'added' to the social, or that it traverses or inflects it, but becomes rather reinscribed as a constitutive 'right' - the right to define and redefine one's infrastructural being. This infrastructural being is what I refer to as a prototype. Unlike previous 
classical designs for complexity in social theory, such as 'comparison' or the 'compatibility' framework of the cyborg and the fractal (Haraway, 1990; Strathern, 2004), where relations are seen to work as being 'more than one and less than many' (Mol and Law, 2002), in the case of the prototype its qualities as an 'infrastructure in beta' offer a way to think socio-technical assemblages as 'more than many and less than one'. The prototype never quite reaches closure (it is always less than itself, less than one) yet it keeps forking and enabling novel extensions of itself (it is always more than its own self-scaling, it is more than many forms of itself). Thus, open source designs aim not so much for closure as for proliferation; less for definition than 'infinition' (Holbraad, 2012) - the prototype as a figure of 'compossibility'. Moreover, prototypes, as we shall see below, call forth a particular socio-technical arrangement for carrying out experimental projects in the city. They summon operational frameworks where the experimental system is not conceived as a technical or expert system to be added or injected into the urban lattice. Nor is it conceived as an infrastructure whose very 'experimental' status shows the extent to which the city's metabolic system is held together by constant upkeep and repair work (Castán Broto and Bulkeley, 2013). Rather, prototypes are always, already 'pre-broken' (Fuller and Haque, 2008, page 30), because their experimental conditions consists precisely in holding themselves up to deconstruction and reassembling. It is also in this sense that they work as 'experiments in living' (Marres, 2012), instantiations of the urban condition as a vital infrastructuring processes.

To this day, however, we remain relatively in the dark as to the actual ways in which open source infrastructural projects may be transforming our urban fabric and condition. We know of the 'splintering' effects of urban infrastructures, the spatial and structural fragmentation and inequalities that their inscription in the landscape brings 
about to urban communities (Graham and Martin, 2001); and we know, too, of their 'split agendas', the ways in which urban policies aiming for inclusiveness and universality of access confront internal frictions and tensions within their government sponsors, often bringing much of this goodwill and impetus to a halt (e.g. Odendaal, 2011). What is less documented, however, is the shape that community-driven, ambient intelligences take when they are inscribed and wired bottom-up as urban prototypes.

The case of Inteligencias Colectivas (IC, Collective Intelligences, www.inteligenciascolectivas.org) offers us a point of entry for exploring some such issues. Inteligencias Colectivas is a project of the Spanish multidisciplinary platform Zoohaus, which functions as an umbrella operation for a variety of urban grassroots and guerrilla architectural collectives. The account that follows is based on two years of ethnographic fieldwork (began in October 2011 and on-going) with a number of the collectives making-up the platform. It has included semi-structured interviews with members of the collectives; archival work on their digital repositories; participating in constructive workshops, online discussions, and regular public seminars on urban and architectural developments in Madrid; and the organisation of a series of 'itinerant' seminars with and about the collectives' work held at the very spaces where they have been intervening. ${ }^{1}$

The IC project was first conceived as a pedagogical experiment for students at various architectural and design faculties in Latin America. The aim of an IC workshop is to have attendants survey and document do-it-yourself, retrofitted, community-driven architectural designs and constructive techniques in their local towns. The IC online repository holds today technical and audio-visual documentation pertaining to dozens of such projects, including for example a bicycle adapted to augment its cargo load, or even to function as a market stall; or the use of car tyres and various types of plastic 
trash to lend structural sustainability to a squatter settlement's roof. The auto-

constructive creativity of Latin America's peri-urban areas has proved an inexhaustible source of inspiration for the IC project (Holston, 1991).
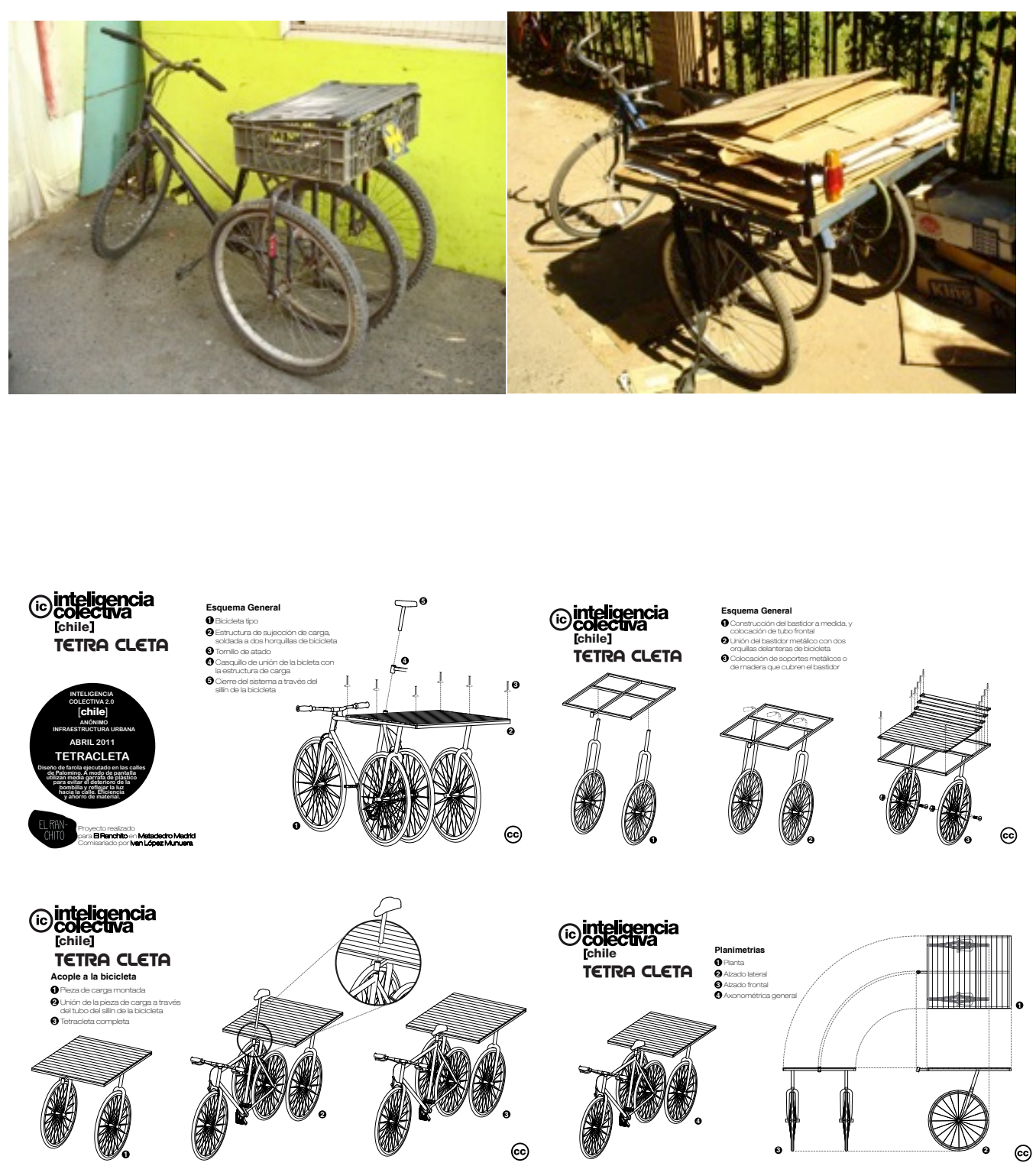

Figures $1 \mathrm{a}, 1 \mathrm{~b}$ and $1 \mathrm{c}$ here. Photographs and technical drawings of a 'tetracycle'. Images by Zoohaus. 
The pedagogical challenge for attendants to an IC workshop is to produce a technical description for each one of the 'intelligences' found. In a sort of reverse engineering, students are required to produce design and technical specifications for such objects and artefacts. The documentation for such designs includes photographs, 3D renderings, architectural sketches and diagrams, textual descriptions, sometimes even video recordings where the author/s of an intelligence is asked to disassemble and re-assemble a piece anew. Every documentary registry is copyrighted with a Creative Commons license, in the event that someone, somewhere, would want to reproduce the intelligence. Members of the IC collective also speak more ambitiously of using an intelligence's documentary and design registry to extend its original capabilities. They refer to this as 'evolutionizing' the intelligence, such that its open source designs may allow for diverse contextual applications: the intelligence is allowed to travel as both open technology and context-specific solution; design and context work as proto and type for each other.

Over the years the crucial design challenge that the IC collective has encountered is to agree on how to stabilize an intelligence's technical description. Unlike the patent specifications of proprietary designs (Biagioli, 2011), there are to this day hardly any standards as to how best to stabilize the epistemic structure of open source hardware. Different designs call for different descriptive standards. The technical specificities of some artefacts are best rendered legible in photographs or 3D renderings; others require long texts to describe, not so much how they are made, but what they are made for. As noted above, a propos the many layers that traverse an open source hardware project, decisions can affect not only the registers in which a component is described (a photograph, a 3D rendering), but also their formats (image quality, file extension), 
languages of description, even the systems required to read/process any of the above; for example, should one use Autodesk, a proprietary software, for making 3D architectural renderings?

As Susan Leigh Star and Geoffrey Bowker have argued, the work of infrastructuring has traditionally been black-boxed to keep standards, conventions and communities of practice at a remove from curious tinkering or political hustling (Leigh Star and Bowker, 2006; Star, 1999). Open source infrastructures, on the other hand, expose all these subtended arrangements and entanglements radically. Their whole orientation is aimed precisely at permanently and recursively 'white-boxing' themselves. Every layer and component of an infrastructure is scrutinized to see whether its design is rendered 'open', and if so, how. In doing so they naturally expose their own fragility and precariousness as infrastructural objects; these can hardly be spoken anymore as robust structures, for every strata shows its internal tensions and deep recursions, its fractures and lines of flight. In this capacity, the frailty of open source hardware would seem in fact to capture the trembling and recalcitrant agency of all infrastructural work at large. As Matthew Fuller and Usman Haque have put it in their 'quasi-license' for open-source architecture, [w]ith respect to opening up the urban design/construction process, and encouraging the reuse and repurposing of architectural artifacts, it is important to ensure that such structures and systems are released in a prebroken condition.' (Fuller and Haque, 2008, page 30, emphasis added) In other words, open-source infrastructures are always, already broken, yet it is precisely this prebroken (beta) status that lends them their durability and sustainability.

Another aspect I would like to bring attention to about the IC project at this stage are its qualities as what Nigel Thrift has called a 'logographic language' (Thrift, 2009). Open source architectural solutions may be thought of as mimetic interfaces, for their 
designs are often developed to dovetail with a specific situation or environment. They are do-it-yourself and hand-tailored infrastructures. In this light, we can see how in setting out to document and describe an intelligence's make-up, the members of Zoohaus also resort to a variety of media 'graphemes' or graphic units of signification. Different intelligences require different media technologies and 'graphematic concatenations' for their description (Rheinberger, 1997, pages 105-108). Some intelligences demand exhaustive diagrammatic analyses, whilst others are faithfully rendered in little more than one photograph. Documenting an intelligence thus calls forth a reinvention of how each technology is described, diagrammatized and signified how it is proto/typed into a standard of sorts. 'The architectural force', Fuller and Haque have noted, 'can be a style, a system, a compositional dynamic, a generative sequence, and/or someone with a good idea or engagement with the learning of a craft. The architect becomes a diagramming force.' (Fuller and Haque, 2008, page 48). We could therefore think of the work of infrastructuring as becoming a purveyor of its own infrasemiotics: an infrastructuring of things and an infrastructuring of cultural meanings, in one and the same movement.

Writing about the objects and artefacts upon which historians of science carry out their labours, John Tresch has coined the term 'cosmogram' to describe the choreography of signifiers - material, inscriptive, iconic - that are drawn together in lending meaning to a 'thing' (Tresch, 2007). The complex amalgamation of media, interfaces, scriptures, materials, ecologies and licenses through which IC designs come into existence perhaps allows for their description as cosmograms in Tresch's sense. Yet I would suggest that in their on-going work as infra-semiotic projects we might do better to think of open source hardware projects as betagrams: iconographic, diagrammatic and more generally symbolic infrastructures that provoke new cosmos 
into existence. ${ }^{2}$ These betagrams re-source the city. That is, they open up the infrastructural lattice of the city to novel and emerging materials, places and resources, resources that are now 're-sourced' openly, and in the process reconfigure the infrastructural geography of the city as a 'post-networked' assemblage (Coutard and Rutherford, 2011; Rutherford, 2011).

A vivid example of one such reconfiguration is provided by one of the developments of the IC project. In 2012, Matadero-Madrid, the city's most important contemporary arts centre, commissioned Zoohaus to turn its online repository of worldwide open source architectural intelligences into an actual, three-dimensional construction. 'What would a free knowledge bank look like', they asked, 'if it were to be designed as an architectural object?'. Zoohaus responded by building a gigantic wooden structure whose design was based on a number of IC intelligences, but which worked also as a self-instructable space, such that it could be expanded or contracted in accordance to users' needs.

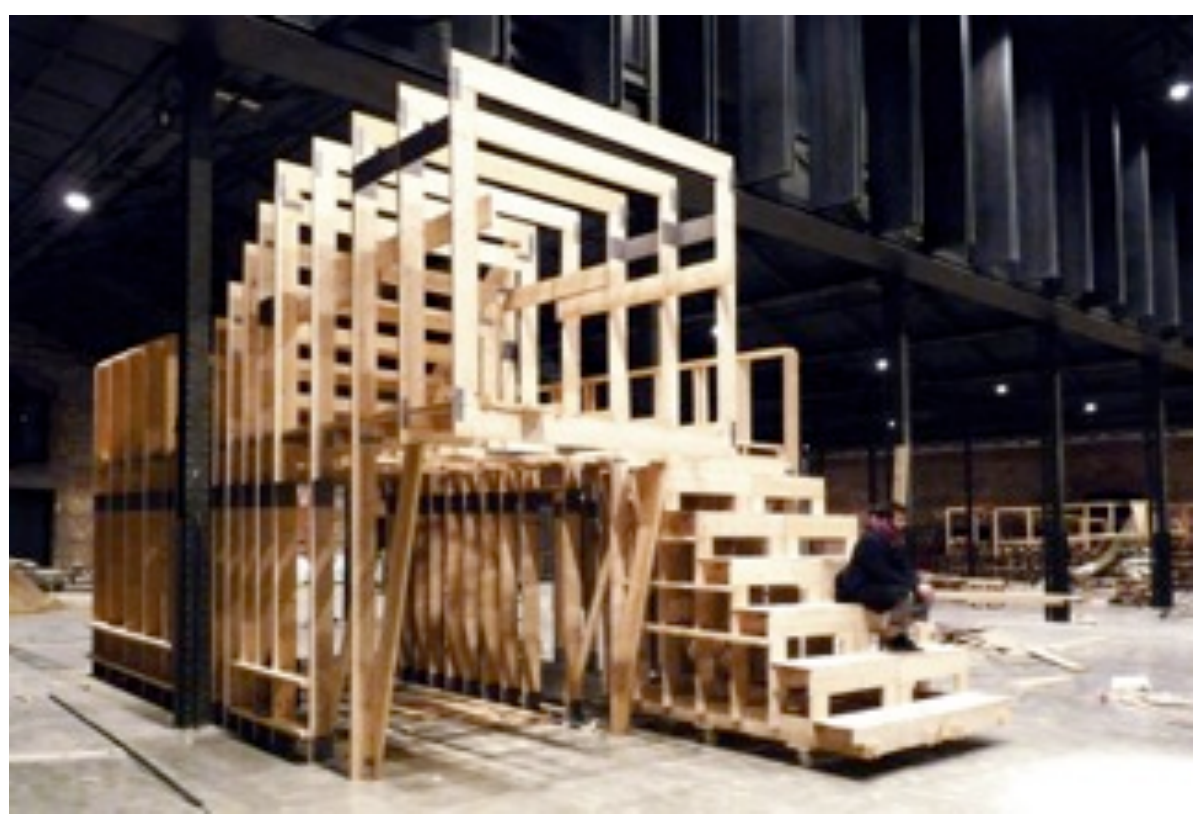




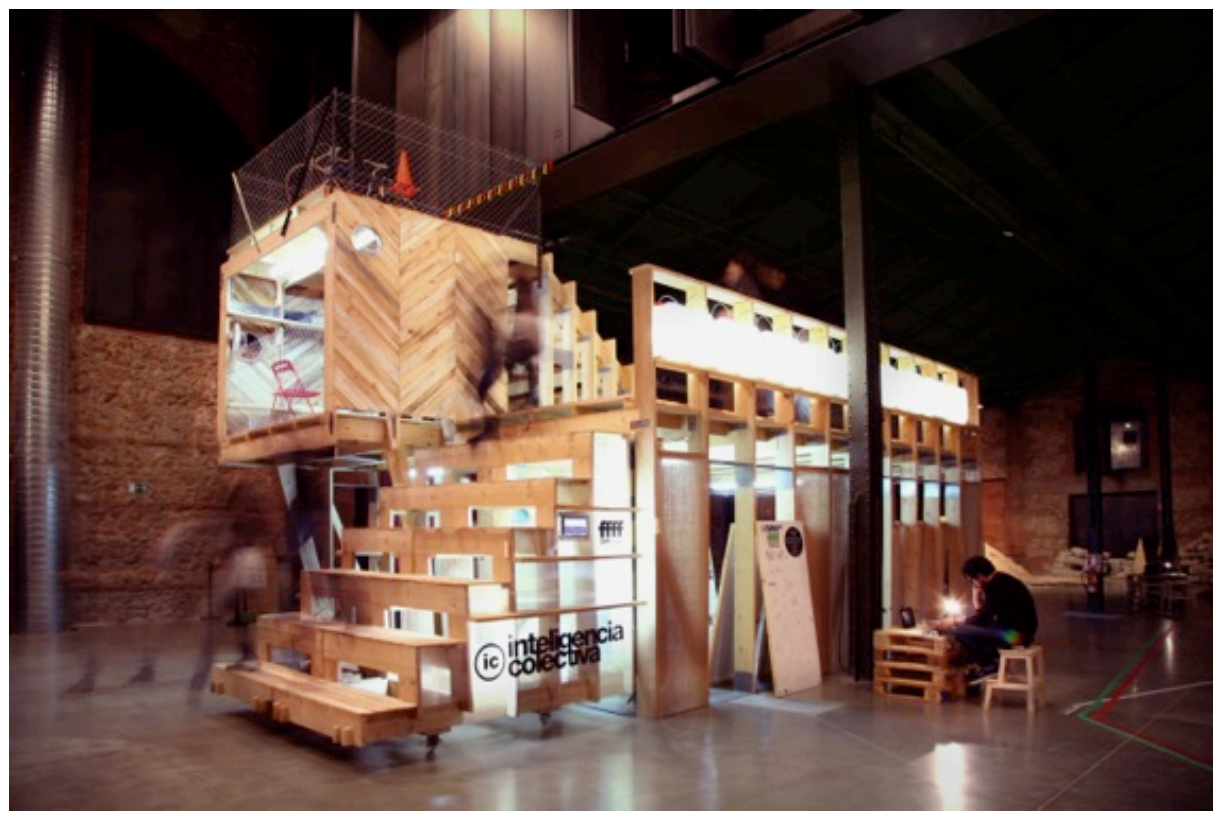

Figure $2 \mathrm{a}$ and $2 \mathrm{~b}$ here. The Offfficina: a meta- and self-instructable architectural intelligence. Images by Zoohaus.

Perhaps most significantly, the structure was wired and equipped to function as an 'office' for all sorts of open source and free culture projects in the vicinity of Matadero. Over the following months the Offfficina, as it was renamed by the architects, became the reference site for all open source architectural matters in Madrid: seminars and debates, book launches or workshops were thenceforth hosted at the Offfficina (for a full description of this project see XXX., In print). In this light, the Offfficina suddenly 'infrastructured' both the intellectual and creative agenda of open source architectural projects in Madrid and their material and constructive needs. In the terms in which Kelty has described free software, the Offfficina worked recursively, both as an argument for open source architecture and its enabling infrastructure. As a gigantic piece of interior design, the Offfficina furnished open source architecture with the conceptual and infrastructural resources necessary for rendering it fully visible and legible - and legitimate - amidst Madrid's architectural circles.

There is a remarkable way, then, in which the Offfficina's status as an open 
source piece of architecture opened-up a particular form of ambient intelligence in the city. Such ambient intelligence was not so much an enhancement-effect of a particular set of digital or technological interfaces as a wholesale urban event in its own right. It reconfigured the city's ecology, not simply, or not only by enlisting new types of intelligences into its relational fabric, but more ambitiously by radically subverting the very status of such an ecology as an epistemic form. In the terms in which I referred to earlier, the Offfficina now 'prototyped' its own ecology - an ecology whose sociotechnical relations were not so much seeking comparison or cyborg-compatibility with elements elsewhere in the urban fabric as to open-up this very fabric to novel compossibles. Or said somewhat differently, the Offfficina shifted the urban ecology from a relational to an (open) infrastructural topos.

There is another derivation of the IC project that helps cast light on this shift. In 2010, some members of the Zoohaus platform joined a group of residents of La Latina neighbourhood in occupying and taking over the management of a vacant lot at the heart of Madrid's historic old quarter. City Hall had once made plans to build a shopping mall and sports complex in that space, but when the financial and economic crisis hit Spain the project was abruptly brought to a halt. An assembly of local neighbours was soon constituted and invested with decision-making powers over the management of the space, which was now renamed, El Campo de la Cebada. They agreed terms of access, use and exploitation for the space. Originally, El Campo was conceived as a 'free culture space', with strict rules prohibiting commercial uses of the space, although in recent months these have been loosened to allow for 'fair trade' and 'break even' activities. In this time, local residents have used El Campo to develop a community garden (which are illegal in Madrid to this day); to stage theatrical, sports and musical events; or to host travelling circuses and children's workshops. In July 
2013 El Campo even hosted its own Summer University. In this light, El Campo would well fare as an example of an urban commons (e.g. Eizenberg, 2012).

In this time, however, the space has also been used by architectural collectives, including members of Zoohaus, as an experimental field-site for grassroots, autoconstructive projects. These collectives have for example organized a number of socalled 'handmade urbanism' workshops where local residents and passers-by have been invited to construct grandstands, toilets, or various community-garden structures with which to furnish El Campo's space. Architects and neighbours have also collaborated in designing and building a set of gigantic workshop tables for use at a local secondary school. Moreover, these structures have also travelled locally and, as users of El Campo put it, 'infrastructured' other activities and events (temporary urban gardens, flea market stalls) elsewhere in the neighbourhood. The designs for all these structures has followed the open source conventions of the original IC project and been made available for download and consultation at their website.

A concern often voiced a propos the infrastructural travels of these objects regards their keeping with extant safety regulations. Although few of the structures designed and developed at El Campo would pose serious threats to human safety, architects and residents have had to confront the challenges that open source infrastructures pose in matters of public liability insurance. Briefly, some people have considered the possibility of setting up an insurance mutuality for the Campo's assembly, which would thence issue its own insurance policies. Although this possibility has not entirely been discarded, along with my colleague Adolfo Estalella we have recently initiated a series of conversations with some of Zoohaus' architects that suggest a slightly different approach to the civil embedding and sustainability of El Campo's infrastructures in the urban landscape. Our proposal for exploring alternative means to underwrite the 
infrastructures' liabilities looks instead at ways to open-up their 'pedagogical capacities'. Our aim is to have local authorities and administrations understand how open source infrastructures work, so that the very concept of what public liability insurance is gets re-inscribed in origin.

To this effect, over the past few months we have been working with Mozilla's Foundation Open Badges technology ${ }^{3}$ in developing an open source educational itinerary for open source infrastructures. The philosophy behind the Open Badges programme mirrors the navigational structure of the Internet as a distributed and decentralised content-holder. Open Badges allow Internet content providers (such as Inteligencias Colectivas) to issue their own 'learning certificates' (the eponymous Badges). The terms of interaction through which visitors to a webpage prove their having acquired a specific set of skills, abilities or knowledge - so-called digital 'evidences' - is left to content providers too. In the last instance, then, our proposal to develop an Open Badges open source educational programme seeks an alternative 'certification' for open source infrastructures. Though in many respects an embryonic and tentative proposal, it is motivated by a radical engagement with the ultimate 'sources' of infrastructural work: the standards and certificates that are required to underwrite public liability insurances. The open source educational approach to infrastructure encourages a deep structural examination of the many and various layers that striate the nature of certification. Our motivations for embarking on such a project are multifarious, although they rehearse some of the qualities that Gabriella Coleman ascribes to the computer hacker ethic (2012): a playful entanglement of aspirations of autonomy, institutional transgression and pedagogical curiosity, which have found in the nature of infrastructure a new urban frontier. Our progress at this stage is too incipient to deserve further commentary, although I shall return to some of its 
theoretical implications at the end of the article.
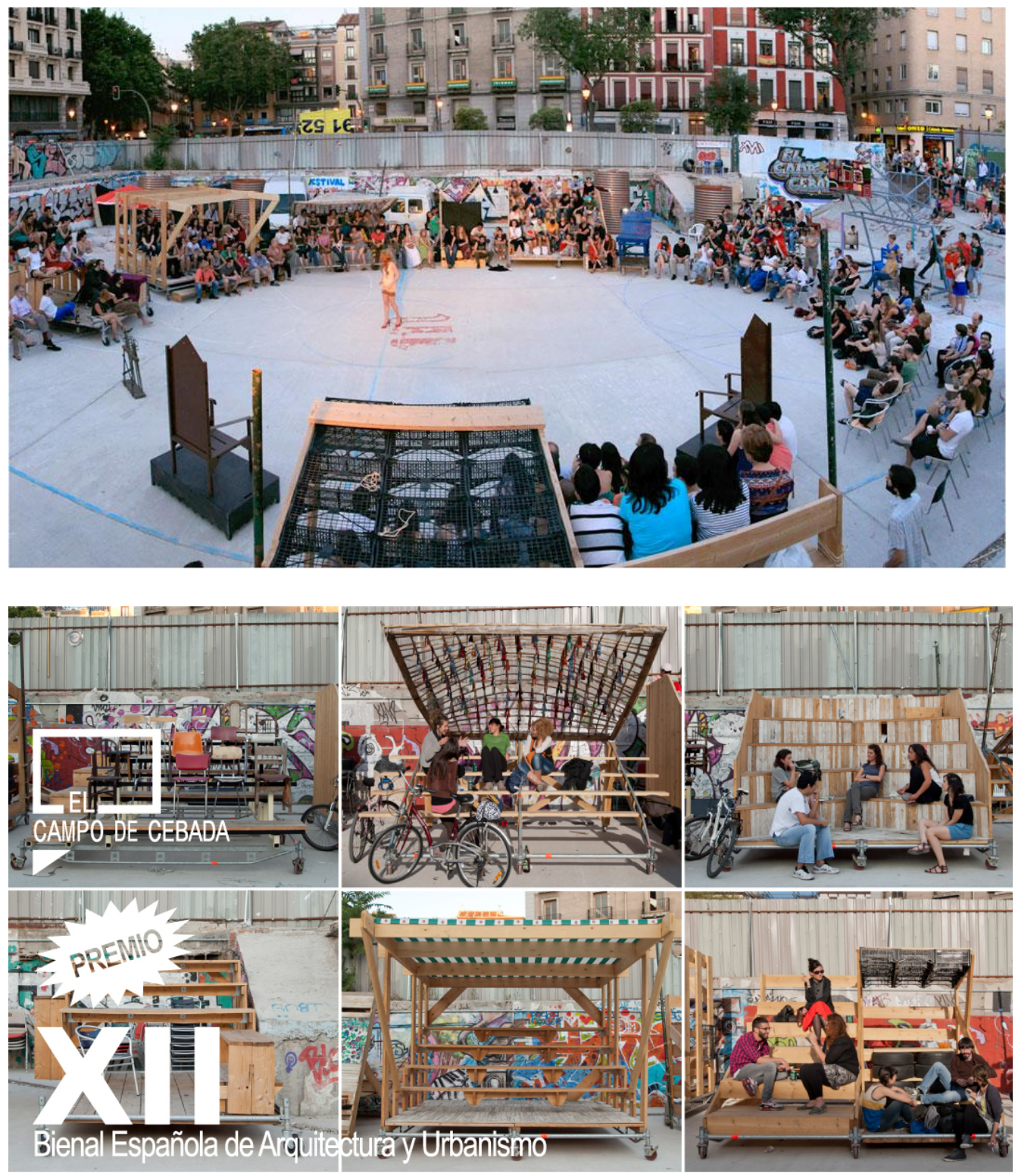

Figure $3 \mathrm{a}$ and $3 \mathrm{~b}$ here. El Campo de Cebada. Images: El Campo de Cebada.

The way in which residents of El Campo have learned to infrastructure their own neighbourhood (schools, gardens, markets) points to an important recent development that bespeaks of a wider transformation in urban governance in Madrid. In October 2012 a number of architectural collectives, squat social centres, cultural agents, 
Madrid's Network of Community Gardens and various other citizens' initiatives came together to discuss their shared experiences of constructing and managing do-it-yourself citizen infrastructures. The first meeting was in fact prompted by a recognition on the part of various actors that the infrastructural projects of El Campo signalled a shift in the terms of governance of urban spaces. The exchange proved productive and it was decided to institutionalise fortnightly meetings. The forum was named, La Mesa (The Roundtable), a designation that intentionally wished to capture both the debating and infrastructural qualities of the forum.

In less than nine months La Mesa's unusual treatment of spatial politics as open source infrastructural developments has already left its mark in Madrid. By the end of 2012, City Hall expressed interest in setting up official interlocution between some of its technical staff and La Mesa. This move challenged almost thirty years of urban politics in Madrid, where City Hall had long obviated all citizen claims that were not channelled through local Neighbourhood Associations. Over the years Neighbourhood Associations in Madrid had monopolized the terms of political engagement and representation at local community levels. However, the Associations' legitimacy has recently come under strenuous pressure, specially since the famous May 152011 protests that gave birth to the Spanish Occupy and popular assemblies movement (locally known as 15M) (XXXX, 2013, 2014). That La Mesa may indeed be infrastructuring local politics in novel ways is perhaps best indicated by Madrid's Federation of Neighbourhood Associations' very own invitation to La Mesa in June 2013 to discuss common interests and develop joint political agendas.

By 2012, El Campo de la Cebada had already become a referent for community spaces all over Spain. In that year El Campo was shortlisted for the European Prize for Urban Public Space. In May 2013 it was presented with the prestigious Digital 
Communities Golden Nica from the world-famous Ars Electronica festival in Linz. In June 2013 it was awarded a first prize from the Spanish Architectural and Urbanism Biennial. These awards have all come as somewhat of a shock to the urban establishment. The Golden Nica in particular surprised commentators and observers alike, who found it difficult to understand how and why a community-managed urban space was awarded an international prize renown for its avant-garde, digital arts interventions.

I would like to venture here that this may respond to El Campo having acquired the properties of an 'urban prototype' as I have defined it above. The activities programmed in El Campo are no doubt circumscribed spatio-temporal events. But they are also iconographic, diagrammatic and more generally symbolic infrastructures that travel in a variety of forms, styles and registers. They work as betagrams. The objects made at a handmade urbanism workshop, for example, travel as open source design documents and technical specifications, which are shared widely in the IC webpage and affinal digital platforms. They also travel in the form of photographs, sketches and diagrams that are posted on Facebook or Twitter by attendants to a workshop or passers-by. But perhaps most importantly, they travel also as infrastructures themselves: they contribute towards the furnishing and equipment of nearby areas, but they also, notably, infrastructure the possibilities for novel political and social relations, with local schools, market vendors, even the local $15 \mathrm{M}$ popular assembly and the Neighbourhood's Association.

In El Campo, then, the residents of La Latina are expressing and voicing a right to infrastructure: a political will to have their city furnished in very specific ways. In this sense, El Campo is a prototype for - a first model or exemplar of - an urban commons in Madrid, as the term has recently been used (Harvey, 2012; Eizenberg, 2012). 
But we may also think of El Campo as right to infrastructure, where the latter reads now as a verb not a noun. That is, when the process of infrastructuring makes visible and legible the languages, media, inscriptions, artefacts, devices and relations the betagrams - through which political and social agencies are endowed with any expressive capacity whatsoever. In other words, when it is the work of infrastructuring that suffuses and furnishes a 'right' with political concrescence in the first place - when infrastructuring provokes worlds and rights and Campos into existence. In this light, El Campo would not so much fare as a prototype for an urban commons as a prototype for itself: an urban system of intelligences 'in beta'.

\section{Conclusion: the right to infrastructure}

Critical urban geography has a distinguished tradition of investigating the relations between urban space, social justice and the conditions of political citizenship (Harvey, 2009; Soja, 2010). Recent scholarship has furthered this agenda by reawakening interest in Henri Lefebvre's famous essay, 'The Right to the City' (Lefebvre, 1996), particularly as regards alternative configurations of democratic participation in urban decisionmaking processes, say, over matters of housing, water, transportation, etc. (Mitchell, 2003; Harvey, 2008). Although the formal and substantive qualities of the 'right to the city' remain contested (is it a moral right, a socio-economic right, a civil liberty?; see Attoh, 2011), the concept has gained purchase of late as a model for re-articulating expressions of insurgent citizenship and on-going struggles over the production and reproduction of urban life.

Whilst the right to the city remains a fairly abstract signifier, in this article I have sought to explore a specific manifestation of public action wherein such rights take expression and 'ground' themselves in concrete infrastructural conditions. My account 
echoes Mark Purcell's recent call to recuperate the Lefebvrian strand in the right to the city (Purcell, 2013): Lefebvre's original inspiration to think of our inhabiting the city not as the reclaiming of a right to political voice within the liberal juridical framework of a state-sanctioned or market-shaped urban geometry, but as an exploration of the very conditions holding together (and yet more often, being receded into the distance) the shifting horizon of our project for democratic-becoming. Democracy, in other words, as a real infra_structure: an on-going and deepening search, reinvention and reappropriation - 'autogestion', in Lefebvre's terms (Purcell, 2013, page 317) - of the radical and receding sources of political conviviality. There is therefore quite literally an infra_structure to every right to the city. This is made especially evident in the study of open source urban hardware projects, where the means and ends of political action converge in very concrete and material objects of infrastructure.

Although there is now a substantial literature in anthropology and critical legal theory on the cultural and social work that goes into the making of rights-based legal knowledge and discourses, much of this work has traditionally focused on reembedding such discourses in larger cultural and political contexts: say, exploring how human rights work by looking at the channels of communications or institutional structures wherein they take shape and travel (Goodale and Merry, 2007); or, inspired by social studies of science approaches, looking at how the making of law advances as archival, documentary and registrar forms are variously formatted and pre-set for circulation and retrieval (Vismann, 2008; Latour, 2009).

As I have developed it here, the right to infrastructure is 'collected' somewhat differently, as its gathers materials, devices, appliances, media systems, interfaces and social relations in a dance of graphematic concatenations. It is a right incarnated in and deployed through very specific - open source - socio-technical designs, interventions 
and affordances. These make their appearance in an urban ecology as prototypes, whose work thereon tends to destabilize epistemic formations because of their sourcing and enabling of new compossibilities. As suggested earlier, we may think of the prototype as a sort of 'infrastructural being': a fluctuating betagram of persons-and-things whose holding processes 'in suspension' lends political, administrative and legal ritual different rhythms and capacities (on legal process as a relation between persons and things, see Pottage and Mundy, 2004).

Thus is that the right to infrastructure also articulates novel designs and avenues for political governance and action in urban settings. Rights to infrastructure prototype the city in ways - conceptual, technical and political - hitherto rarely if ever described nor analysed. The cases of Inteligencias Colectivas and El Campo de la Cebada are illustrative. These projects have made visible novel systems of urban intelligences. They have quite literally equipped the city with novel conceptual hardware, including technical designs and medial systems, as well as actual material interventions. Notwithstanding the fragility or precariousness of some of these intelligences, their design and deployment as open source infrastructures lays them open, out and across neighbourhoods of capacities that are at once structurally deep and topological extensive - less than one and more than many.

In this guise, open source infrastructures surely evince a material politics (Braun and Whatmore, 2010; Marres and Lezaun, 2011). And they are no doubt interventions in the 'making of things public' too (Latour and Weibel, 2005). In fact, open source infrastructure projects invite a reconsideration of the very techno-material nature of that thing called 'public' or 'commons' (Domínguez Rubio and Fogué, 2013; Eizenberg, 2012), for these are now better conceptualized as a 'recursive' processes. Moreover, it seems reasonable to suggest that in the case of hardware the layers, strata and striations 
that tense a design as it struggles for openness are further complicated by their systemic spilling-over across equipment, territories, people, and relations. The affordances of 'open source' would thus somewhat seem to take the contours of an emerging, terraforming nomos. A land in-formation (cf. Thrift, 2012).

It is on this note that I would like to conclude. Objects and devices, we have seen, press and enact material exigencies over social relations. As Latour famously put it, 'technology is society made durable' (Latour, 1991). However, such durability is as much an accomplishment of the material affordances of devices as is of the work invested in their standardisation, classification and stabilization (Bowker and Star, 2000; Lampland and Leigh Star, 2009). In the case of open source infrastructures these processes are deliberately kept open to scrutiny and re-adaptation. They are designed to be structurally unstable, to prevent their being black-boxed. Indeed, their very vocation may be defined as infinitive white-boxing. However, in doing so they are also terraforming the nature of what counts as 'infrastructure'. There is a very real sense in which every process of infrastructuring undoes itself.

And herein lies the challenge. In the figure of the prototype social theory confronts a world of objects whose epistemic status is to remain forever in suspension, in beta. Worlds whose materiality assumes unstable yet productive awakenings, aiming not for comparison or compatibility with its surrounding urban environment, neither to model nor exemplify urban societies and projects elsewhere, but simply aspiring to work as open infrastructural beings: sources for on-going compossibilities. Faced with such kinds of objects we may want to ask ourselves about the very infrastructural nature of our own theoretical equipment: what sort of tools might the social sciences draw-on to have their theories prototype themselves? I have intimated above how the members of Zoohaus and residents of El Campo, in seeking a solution to the underwriting of 
public liability insurance for their infrastructures, embarked on an investigation into the very nature of the city as an open educational frontier. That would seem a promising space from which to ground the right to infrastructure of theory too.

\section{Acknowledgements}

The argument developed in this article is a synthesis of work carried out over the past four years in close collaboration with many people. In particular I would like to thank Adolfo Estalella for his intellectual companionship throughout this time. The notion of a 'right to infrastructure' is in many respects a crystallisation of our needs for prototyping, reassembling and infrastructuring our joint fieldwork and reflections. Antonio Lafuente has also been a source of inspiration, support and collegiality. Marcos García, Laura Fernández and the staff at Medialab-Prado, Madrid, first sparked our interest in prototypes, which Adolfo and I since pursued and chased into various urban domains. More recently, we have been very lucky to find in Manuel Palacio \& Aurora Adalid (Zuloark), Manuel Polanco Pérez-Llantada \& Rubén Lorenzo Montero \& Juan López-Aranguren Blázquez \& Alberto Nanclares (Basurama), Mauro Gil-Fournier (VIC) and Azucena Klett a fellowship of infrastructural interests.

\section{References}

Anon. OSHW draft - Definition of Free Cultural Works. http://freedomdefined.org/OSHW_draft.

Arbona, J, 2010, "Dangers in the air: aerosol architecture and its invisible landscapes", in Air (MIT Press, Cambridge, Mass.), pp 81-97.

Attoh, K A, 2011, "What kind of right is the right to the city?" Progress in Human 
Geography 35(5) $669-685$.

Benjamin, D, Yang, S-I, and Jeremijenko, N, 2011, "New interaction partners for environmental governance: amphibious architecture", in Sentient City: Ubiquitous Computing, Architecture, and the Future of Urban Space (MIT Press, Cambridge, MA and London), pp 48-63.

Benkler, Y, 2011 The penguin and the Leviathan: how cooperation triumphs over selfinterest (Crown Business, New York).

Benkler, Y, 2006 The wealth of networks: how social production transforms markets and freedom (Yale University Press, New Haven).

Biagioli, M, 2011, "Patent specification and political representation", in Making and unmaking intellectual property: creative production in legal and cultural perspective Eds M Biagioli, P Jaszi, and M Woodmansee (The University of Chicago Press, Chicago and London), pp 25-39.

Biagioli, M, Jaszi, P, and Woodmansee, M eds., 2011 Making and unmaking intellectual property: creative production in legal and cultural perspective (The University of Chicago Press, Chicago and London).

Bowker, G C and Star, S L, 2000 Sorting Things Out: Classification and Its Consequences (MIT Press).

Boyle, J, 2008 The public domain: enclosing the commons of the mind (Yale University Press, New Haven and London).

Braun, B and Whatmore, S J, 2010 Political Matter: Technoscience, Democracy, and Public Life (University of Minnesota Press, Minneapolis).

Burke, A and Tierney, T eds., 2007 Network Practices (Princeton Architectural Press).

Castán Broto, V and Bulkeley, H, 2013, "Maintaining Climate Change Experiments: Urban Political Ecology and the Everyday Reconfiguration of Urban 
Infrastructure" International Journal of Urban and Regional Research (online version published ahead of print) doi/10.1111/1468-2427.12050

Coleman, E G, 2012 Coding Freedom: The Ethics and Aesthetics of Hacking (Princeton University Press, New Jersey).

Coleman, E G and Golub, A, 2008, "Hacker practice: moral genres and the cultural articulation of liberalism" Anthropological Theory 8(3) 255 -277.

XXXX, In print, "Introduction. The prototype: more than many and less than one" Journal of Cultural Economy.

XXXX, 2014, "Assembling neighbours: the city as hardware, method, and a 'very messy kind of archive"" Common Knowledge 20(1).

XXXX, 2013, "The atmospheric person: value, experiment and 'making neighbours' in Madrid's popular assemblies" HAU. Journal of Ethnographic Theory 3(2).

XXXX, In print, "The interior design of (free) knowledge" Journal of Cultural Economy.

Coutard, O and Rutherford, J, 2011, "Post-networked cities: recombining infrastructural ecological and urban transitions", in Cities and Low Carbon Transitions Eds H Bulkeley, V Castán Broto, V Hodson et. al. (Routledge, London), pp 107-125.

Crang, M and Graham, S, 2007, "Sentient Cities: Ambient intelligence and the politics of urban space" Information, Communication \& Society 10(6) 789-817.

Domínguez Rubio, F and Fogué, U, 2013, “Technifying Public Space and Publicizing Infrastructures: Exploring New Urban Political Ecologies through the Square of General Vara del Rey” International Journal of Urban and Regional Research 37(3) 1035-1052.

Eizenberg, E, 2012, “Actually Existing Commons: Three Moments of Space of Community Gardens in New York City" Antipode 44(3) 764-782. 
Foray, D, 2006 The economics of knowledge (The MIT Press, Cambridge, Mass., and London).

Gandy, M, 2005, "Cyborg Urbanization: Complexity and Monstrosity in the Contemporary City" International Journal of Urban and Regional Research 29(1) $26-49$.

Ghosh, R A, 2005 CODE: collaborative ownership in the digital economy (The MIT Press, Cambridge, Mass. and London).

Gillespie, T, 2007 Wired Shut: Copyright and the Shape of Digital Culture (The MIT Press).

Goodale, M and Merry, S E eds., 2007 The Practice of Human Rights: Tracking Law Between the Global and the Local (Cambridge University Press).

Graham, S, 2010 Cities Under Siege: The New Military Urbanism (Verso Books, London and New York).

Graham, S and Martin, S, 2001 Splintering Urbanism: Networked Infrastructures, Technological Mobilities and the Urban Condition (Routledge, London).

Fuller, M and Haque, U, 2008 Urban Versioning System 1.0 (The Architectural League of New York Situated Pamphlet Series, New York).

Haraway, D, 1990, “A manifesto for cyborgs: science, technology, and socialist feminism in the 1980s", in Feminism/Postmodernism Ed L J Nicholson (Routledge, New York and London), pp 190-233.

Harvey, D, 2012 Rebel Cities: From the Right to the City to the Urban Revolution (Verso Books).

Harvey, D, 2009 Social justice and the city (University of Georgia Press, Athens).

Harvey, D, 2008, “The right to the city” New Left Review 53 23-40.

Hess, C and Ostrom, E, 2003, "Ideas, Artifacts, and Facilities: Information as a 
Common-Pool Resource" Law and Contemporary Problems 66(1/2) 111-145.

Hess, C and Ostrom, E, 2006 Understanding knowledge as a commons: from theory to practice (The MIT Press, Cambridge, Mass.).

Holbraad, M, 2012 Truth in motion: the recursive anthropology of Cuban divination (Chicago University Press, Chicago and London).

Holston, J, 1991, “Autoconstruction in Working-Class Brazil” Cultural Anthropology 6(4) 447-465.

Kelty, C M, 2011, “Inventing copyleft”, in Making and unmaking intellectual property: creative production in legal and cultural perspective Eds M Biagioli, P Jaszi, and M Woodmansee (The University of Chicago Press, Chicago and London), pp $133-148$.

Kelty, C M, 2008 Two bits: the cultural significance of free software (Duke University Press, Durham and London).

Lampland, M and Leigh Star, S eds., 2009 Standards and Their Stories: How Quantifying, Classifying, and Formalizing Practices Shape Everyday Life (Cornell University Press, Ithaca, New York).

Latour, B, 1991, "Technology is society made durable", in A sociology of monsters: essays on power, technology and domination Ed J Law (Routledge, London), pp $103-131$.

Latour, B, 2009 The making of law: an ethnography of the Conseil d'État (Polity, Malden, MA, and Cambridge).

Latour, B and Weibel, P, 2005 Making things public: atmospheres of democracy (The MIT Press, Cambridge, Massachusetts, and London).

Lefebvre, H, 1996, “The right to the city”, in Writings on Cities Eds E Kofman and E Lebas (Blackwell), pp 147-159. 
Leigh Star, S and Bowker, G C, 2006, "How to infrastructure", in Handbook of new media: social shaping and social consequences of ICTs (SAGE, London; Thousand Oaks [Calif.]), pp 230-245.

MacKenzie, A, 2006 Transductions: Bodies and Machines at Speed (Continuum, London and New York).

Marres, N, 2012, “The Experiment in Living”, in Inventive Methods: The Happening of the Social Eds C. Lury and N. Wakeford (Routledge, London), pp 76-95.

Marres, N and Lezaun, J, 2011, "Materials and devices of the public: an introduction" Economy and Society 1-21.

McCullough, M, 2005 Digital Ground: Architecture, Pervasive Computing, And Environmental Knowing (Mit Press, Cambridge, MA and London).

Mitchell, D, 2003 The Right to the City: Social Justice and the Fight for Public Space (Guilford Press, New York and London).

Mol, A and Law, J, 2002, “Complexities: an introduction”, in Complexities: social studies of knowledge practices Eds J Law and A Mol (Duke University Press, Durham and London), pp 1-22.

Odendaal, N, 2011, "Splintering Urbanism or Split Agendas? Examining the Spatial Distribution of Technology Access in Relation to ICT Policy in Durban, South Africa" Urban Studies 48(11) 2375-2397

Pottage, A and Mundy, M, 2004 Law, Anthropology, and the Constitution of the Social: Making Persons and Things (Cambridge University Press).

Purcell, M, 2013, "The right to the city: the struggle for democracy in the urban public realm" Policy \& Politics 43(3) 311-327.

Rheinberger, H-J, 1997 Toward a history of epistemic things: synthesizing proteins in the test tube (Stanford University Press, Stanford, California). 
Rutherford, J, 2011, "Rethinking the Relational Socio-Technical Materialities of Cities and ICTs" Journal of Urban Technology 18(1) 21-33.

Sadler, S, 2005 Archigram: Architecture Without Architecture (MIT Press, Cambridge, MA and London).

Sadler, S, 1999 The Situationist City (MIT Press, Cambridge, MA and London).

Sassen, S, 2011, “Unsettling topographic representation”, in Sentient City: Ubiquitous Computing, Architecture, and the Future of Urban Space (MIT Press, Cambridge, MA and London), pp 182-189.

Shepard, M, 2011a Sentient City: Ubiquitous Computing, Architecture, and the Future of Urban Space (MIT Press, Cambridge, MA and London).

Shepard, M, 2011b, “Toward the sentient city", in Sentient City: Ubiquitous Computing, Architecture, and the Future of Urban Space (MIT Press, Cambridge, MA, and London), pp 16-37.

Soja, E W, 2010 Seeking Spatial Justice (University of Minnesota Press, Minneapolis).

Star, S L, 1999, “The Ethnography of Infrastructure” American Behavioral Scientist 43(3) 377-391.

Strathern, M, 2004 Partial connections (AltaMira Press, Walnut Creek).

Swyngedouw, E, 1996, “The city as a hybrid: On nature, society and cyborg urbanization" Capitalism Nature Socialism 7(2) 65-80.

Swyngedouw, E and Heynen, N C, 2003, "Urban Political Ecology, Justice and the Politics of Scale" Antipode 35(5) 898-918.

Thrift, N, 2009, "Different atmospheres: of Sloterdijk, China, and site" Environment and Planning D: Society and Space 27(1) 119 - 138.

Thrift, N, 2012, “The insubstantial pageant: producing an untoward land" Cultural Geographies 19(2) 141-168. 
Tresch, J, 2007, “Technological World - Pictures: Cosmic Things and Cosmograms" Isis 98(1) 84-99.

Turner, F, 2006 From counterculture to cyberculture: Stewart Brand, the Whole Earth network, and the rise of digital utopianism (The University of Chicago Press, Chicago).

Vismann, C, 2008 Files: law and media technology (Stanford University Press, Stanford, California).

Wark, M, 200850 Years of Recuperation of the Situationist International (Princeton Architectural Press, New York).

Wiener, N, 1989 The human use of human beings: cybernetics and society (Free Association Books, London).

\section{Notes}

\footnotetext{
${ }^{1}$ The seminar series, which went under the title, 'Taking critique out for a walk' (Sacar la crítica a paseo), ran from April to June 2013: http://www.prototyping.es/la-critica-apaseo.

${ }^{2}$ A provocation, understood as both a manoeuvre aimed at destabilizing or disrupting, but also as pro-vocation: an exercise that strives to bring or extract new voices out into the world.

${ }^{3}$ See http://openbadges.org/
} 